\title{
Analisis Buku Teks Pelajaran Matematika SMP ditinjau dari Literasi Matematika
}

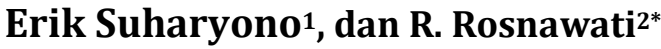 \\ Pendidikan Matematika, FMIPA, Universitas Negeri Yogyakarta \\ Jalan Colombo No 1, Yogyakarta, DI Yogyakarta, Indonesia \\ 1ericksuharyono@gmail.com; ${ }^{2 *}$ rosnawati@uny.ac.id
}

Artikel diterima: 23-07-2020, direvisi: 28-09-2020, diterbitkan: 30-09-2020

\begin{abstract}
Abstrak
Literasi matematika merupakan salah satu tujuan pembelajaran matematika sehingga perlu termuat dalam buku teks matematika sebagai sumber utama belajar. Penelitian ini bertujuan untuk mendeskripsikan hasil analisis soal-soal pada buku teks pelajaran matematika SMP kelas VII semester II kurikulum 2013 ditinjau dari literasi matematika. Jenis penelitian yang digunakan adalah penelitian deskriptif. Data dikumpulkan melalui teknik pengkodean, dan teknik analisis data menggunakan statistik deskriptif. Hasil penelitian menunjukkan bahwa dari 408 soal yang dianalisis, terdapat $49,26 \%$ soal serupa dengan soal-soal pada PISA. Proporsi konteks didominasi oleh konteks umum dengan persentase $42,29 \%$. Aspek proses didominasi oleh proses menggunakan konsep, fakta, prosedur, dan penalaran dengan persentase $66,17 \%$. Selanjutnya, Level kompetensi matematika PISA didominasi oleh level 2 dengan persentase $52,74 \%$ dan level 1 dengan persentase 39,80\%. Kurang dari 10\% untuk level 3 sampai 6 . Hal tersebut berarti bahwa soal-soal pada buku teks hanya mampu melatih peserta didik di level 2 kompetensi matematika PISA. Diperlukan sumber belajar lainnya yang dapat melengkapi kekurangan tersebut.

Kata Kunci: buku teks, literasi matematika, PISA
\end{abstract}

\section{Analysis of Mathematics Textbooks for Middle School based on Mathematics Literacy}

\begin{abstract}
Mathematical literacy skills are one of the goals of learning mathematics, so that mathematical literacy needs to be included in mathematics textbooks as the main source of learning. The purposed study is to describe mathematical literacy in the items of a question in the $7^{\text {th }}$ secondsemester mathematic textbooks. This study was descriptive research. Data were collected through coding techniques. The reliability coefficient of the data is 0,909 . The results indicate that of the 408 items question, there is $49.26 \%$ that were similar to the questions on PISA. The dominated aspect of context is the societal context by $42.29 \%$. The dominated process aspect is mathematical concepts, facts, procedures, and reasoning by $66.17 \%$. Furthermore, the dominated PISA's mathematics competency level is level 2 by $52.74 \%$ and level 1 by $39.80 \%$. Less than $10 \%$ for levels 3 to 6 . This means that the questions in the textbook are only able to train students in level 2 PISA mathematics competence. Other learning resources are needed that can complement these shortcomings

Keyword: textbook, mathematics literacy, PISA
\end{abstract}




\section{Pendahuluan}

Terdapat berbagai macam sumber belajar dalam menunjang proses pembelajaran, salah satunya yang dominan digunakan, bahkan di era digitalisasi adalah buku teks. Berdasarkan hasil penelitian TIMSS pada tahun 2011 (IEA, 2012: 19) menunjukkan secara internasional bahwa dalam pembelajaran matematika guru lebih sering menggunakan buku teks sebagai dasar dalam pembelajaran. Hasil penelitian yang dilakukan oleh TIMSS yang dikombinasikan dengan Hiebert (World Bank, 2010: 56) juga menunjukkan bahwa 93\% sekolah di Indonesia menggunakan buku teks sebagai sumber belajar dan mengajar.

Menurut Loveridge buku teks memenuhi syarat tertentu dalam kegiatan belajar mengajar dan disusun secara sistematis untuk diasimilasikan (Muslich 2010: 50). Sedangkan menurut Chambliss \& Calfee (Muslich 2010: 50), buku teks adalah alat bantu peserta didik untuk memahami dan belajar dari hal-hal yang dibaca dan untuk memahami dunia. Oleh karena itu, buku teks disusun untuk menunjang program pembelajaran (Muslich, 2010: 51), tidak terkecuali dalam pembelajaran matematika.

Guru-guru menggunakan buku teks untuk merancang, memilih tugas-tugas, dan melaksanakan pembelajaran matematika. Buku teks ini memiliki peran yang sangat penting di dalam menentukan keberhasilan pembelajaran matematika (Matic \& Gracin, 2016). Rezat (2013) mengemukakan bahwa buku teks matematika digunakan untuk berlatih secara mandiri, penyajian dalam buku teks mempengaruhi peserta didik dalam menggunakan buku ini. Čeretková, Šedivý, Molnár \& Petr (2008:30) menyatakan bahwa buku teks matematika harus mengembangkan sikap yang disesuaikan dengan tujuan kompetensi yang diharapkan. Sedangkan Li, Zhang, \& Ma (2009: 743) mengungkapkan bahwa buku teks harus membangkitkan minat peserta didik dalam belajar matematika.

Literasi matematika juga dapat membantu individu dalam mengenali peran yang dimainkan matematika di dunia dan untuk membuat penilaian yang kuat dan keputusan yang dibutuhkan oleh warga negara yang konstruktif, partisipatif, dan reflektif (OECD, 2016). Kemudian, menurut De Lange (2006), literasi matematika merupakan masalah di dunia nyata, artinya masalah ini tidak murni tentang matematika namun ditempatkan ke dalam suatu situasi. Singkatnya, Ojose (2011) mendefinisikan literasi matematika sebagai suatu pengetahuan untuk menerapkan dasar matematika dalam kehidupan seharihari.

Literasi matematika sangat membantu untuk menyelesaikan masalah sehari-hari yang berkaitan dengan matematika. Muzaki \& Masjudi (2019) menunjukkan kemampuan literasi matematika siswa masih berada dalam kategori rendah. Perlu upaya untuk dapt meningkatkan kemampuan literasi matematika, salah 
satunya melalui buku teks sebagai sumber belajar. Saat ini buku teks pelajaran berbentuk buku siswa dan buku guru yang merupakan terbitan Kemdikbud.

Penelitian Masduki, Subandriah, Irawan, dan Prihantoro (2013:978) mengonfirmasi laporan TIMSS dan PISA yang menilai kemampuan matematika peserta didik Indonesia lemah, yaitu karena peserta didik tidak terbiasa dalam mengerjakan soal-soal yang melibatkan kemampuan bernalar. Selain itu, Kajander dan Lovric (2009:173) mengemukakan tentang potensi buku teks dalam menyebabkan kesalahan konsepsi pada peserta didik.

Telah banyak penelitian yang dilakukan terhadap buku teks, khususnya buku teks Kurikulum 2013 namun masih jarang penelitian yang membahas tentang kesesuaian soal-soal pada buku apabila ditinjau dari literasi matematika. Untuk melihat kesesuaian soal-soal pada buku teks ditinjau dari literasi matematika dapat diukur dengan menggunakan aspek penilaian PISA serta 6 level kompetensi matematika PISA. Penelitian ini diharapkan dapat mengetahui bagaimana kesesuaian kesesuaian soal-soal pada buku apabila ditinjau dari literasi matematika.

\section{Metode}

Metode penelitian yang digunakan adalah penelitian deskriptif dengan pendekatan kuantitatif. Objek yang digunakan dalam penelitian ini adalah buku teks pelajaran matematika SMP kelas VII semester II Kurikulum 2013 terbitan
Kemdikbud edisi revisi 2017. Pemilihan buku sampel didasarkan pada pertimbangan buku terbanyak yang digunakan oleh sekolah. Instrumen yang digunakan untuk pengumpulan data pada penelitian ini adalah lembar penilaian tentang soal-soal yang terdapat pada buku ditinjau dari aspek penilaian PISA yang meliputi proses, konten, dan konteks serta 6 level kompetensi matematika pada PISA 2018. Kisi-kisi instrumen tampak pada Tabel 1. Teknik analisis data dilakukan melalui lima tahap, yaitu (1) pendefinisian unit, (2) penkodean, (3) reduksi, (4) penarikan kesimpulan, dan (5) pendeskripsian.

Tabel 1.

Kisi-kisi instrumen

\begin{tabular}{|c|c|c|}
\hline \multicolumn{2}{|c|}{ Aspek } & Indikator \\
\hline \multirow{3}{*}{\multicolumn{2}{|c|}{ Proses }} & $\begin{array}{l}\text { Menggunakan konsep matematika, } \\
\text { fakta, prosedur, dan penalaran }\end{array}$ \\
\hline & & $\begin{array}{l}\text { Merumuskan masalah secara } \\
\text { matematis }\end{array}$ \\
\hline & & $\begin{array}{l}\text { Menafsirkan, menerapkan, dan } \\
\text { mengevaluasi hasil matematika }\end{array}$ \\
\hline \multirow{4}{*}{\multicolumn{2}{|c|}{ Konteks }} & Pribadi (personal) \\
\hline & & Pekerjaan (occupational) \\
\hline & & Umum (societal) \\
\hline & & Keilmuan (scientific) \\
\hline \multirow{4}{*}{ 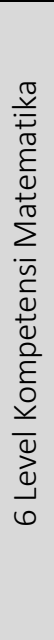 } & 1 & $\begin{array}{l}\text { Memuat konteks yang umum } \\
\text { (kegiatan sehari-hari) } \\
\text { Informasi dan pertanyaan pada soal } \\
\text { didefinisikan secara jelas }\end{array}$ \\
\hline & 2 & $\begin{array}{l}\text { Terdapat berbagai macam informasi } \\
\text { atau informasi yang perlu } \\
\text { disimpulkan terlebih dahulu }\end{array}$ \\
\hline & 3 & $\begin{array}{l}\text { Memuat prosedur yang dijelaskan } \\
\text { dengan jelas untuk menyelesaikan } \\
\text { permasalahan }\end{array}$ \\
\hline & 4 & $\begin{array}{l}\text { Memuat situasi yang kongkret } \\
\text { tetapi kompleks, menimbulkan } \\
\text { asumsi peserta didik, dan } \\
\text { memerlukan transformasi masalah } \\
\text { ke model matematika }\end{array}$ \\
\hline
\end{tabular}


5 Menuntut berbagai strategi

6 Menuntut generalisasi

\section{Hasil dan Pembahasan}

Hasil analisis yang telah dilakukan menunjukkan bahwa soal-soal pada buku teks matematika SMP kelas VII Kuriulum 2013 terbitan Kemdikbud edisi revisi 2017 semester II memuat soal yang sesuai dan tidak sesuai dengan aspek penilaian PISA. Hasil tersebut disajikan ke dalam Tabel 2 yang memuat hasil klasifikasi butir soal serupa PISA dan non PISA pada tiap bab dan uji kompetensi semester II untuk melihat soal yang serupa dengan PISA baik per bab maupun secara keseluruhan.

Tabel 2.

\begin{tabular}{|c|c|c|c|c|c|c|c|c|}
\hline \multirow{2}{*}{$\begin{array}{l}\text { Jenis } \\
\text { soal }\end{array}$} & \multicolumn{5}{|c|}{ Latihan Bab } & \multirow{2}{*}{$\begin{array}{c}\text { UK } \\
\text { S } \\
\text { II }\end{array}$} & \multirow[t]{2}{*}{$\Sigma$} & \multirow[t]{2}{*}{$\%$} \\
\hline & $\mathrm{V}$ & $\mathrm{VI}$ & VII & VIII & IX & & & \\
\hline $\begin{array}{l}\text { Serup } \\
\text { a PISA }\end{array}$ & 60 & 67 & 8 & 17 & $\begin{array}{l}3 \\
8\end{array}$ & 11 & $\begin{array}{c}20 \\
1\end{array}$ & $\begin{array}{c}49,2 \\
6\end{array}$ \\
\hline $\begin{array}{l}\text { Non } \\
\text { PISA }\end{array}$ & 10 & 7 & 74 & 96 & 1 & 19 & $\begin{array}{c}20 \\
7\end{array}$ & $\begin{array}{c}50,7 \\
4\end{array}$ \\
\hline $\begin{array}{l}\text { Jumla } \\
\text { h }\end{array}$ & 70 & 74 & 82 & $\begin{array}{c}11 \\
3\end{array}$ & $\begin{array}{l}3 \\
9\end{array}$ & 30 & $\begin{array}{c}40 \\
8\end{array}$ & 100 \\
\hline
\end{tabular}

Berdasarkan Tabel 2, terdapat 408 butir soal yang dianalisis dalam buku tersebut yang berasal dari 2 bagian yaitu soal pada bagian Ayo Kita Berlatih dan Uji Kompetensi. Dari 408 soal tersebut terdapat 201 soal yang serupa dengan PISA dengan persentase 49,26\% dan sisanya 207 soal non PISA dengan persentase 50,74 \%. Soal-soal non PISA paling banyak ditemukan pada bab VII, VIII dan UKS II. Soal-soal non PISA pada buku tersebut secara keseluruhan disajikan tanpa memuat konteks yang merupakan salah satu aspek dalam aspek penilaian PISA. Konteks merupakan aspek yang penting, karena berdasarkan definisi menyebutkan bahwa literasi matematika merupakan kapasitas individu untuk memformulasikan, mengunakan, dan menafsirkan matematika dalam berbagai konteks (OECD, 2019). Penyajian konteks dalam pembelajaran matematika dapat disajikan melalui pembelajaran berbasis masalah sehingga meningkatkan kemampuan literasi siswa (Fatwa, Septian, \& Inayah, 2019).

Salah satu contoh soal pada bab VII dapat dilihat pada Gambar 1. Soal tersebut merupakan contoh soal non PISA, karena tidak memuat konteks yang terdapat pada dunia nyata. Soal hanya memuat gambar dan perintah untuk menentukan nilai $p$. Ojose (2011) menjelaskan bahwa literasi matematika harus menerapkan dasar matematika dalam kehidupan sehari-hari sehingga soal dengan tipe tersebut tidak dapat melatih kemampuan literasi matematika.

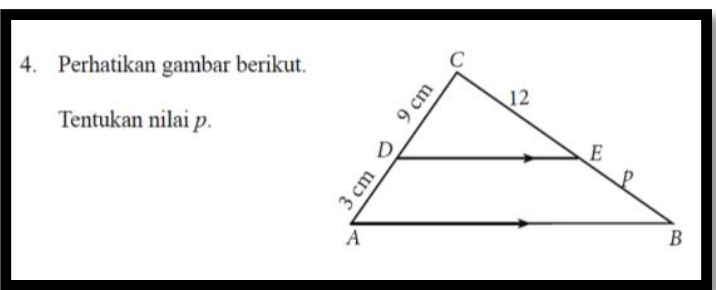

Gambar 1. Contoh Soal Tanpa Konteks

Pada bab VII terdapat beberapa soalsoal olimpiade seperti OSK dan OSN serta soal-soal ujian nasional. Soal-soal tersebut membutuhkan penalaran tingkat tinggi untuk dapat menyelesaikannya. Namun, soal-soal tersebut tidak dapat melatih 
kemampuan literasi matematika peserta didik karena tidak memuat konteks.

Hasil analisis yang berkaitan dengan konten, proses dan konteks dapat dilihat pada Tabel 3 yang memuat persentase hasil analisis butir soal pada buku menggunakan aspek penilaian PISA untuk mengetahui banyaknya soal yang serupa dengan PISA dari tiap aspek indikator.

Konten yang paling banyak ditemukan adalah konten kuantitas dengan persentase 67,16 \%. Konten kuantitas dapat ditemukan dalam bab $V$ dengan materi Perbandingan dan bab VI dengan materi Aritmetika Sosial. Proses menggunakan konsep matematika, fakta, prosedur, dan penalaran mendominasi aspek proses dengan jumlah soal 133 soal dengan persentase $66,17 \%$. Konteks umum mendominasi aspek konteks dengan persentase $42,29 \%$.

Tabel 3.

Analisis Butir Menggunakan Aspek Penilaian PISA

\begin{tabular}{|c|c|}
\hline Aspek Penilaian PISA & $\%$ \\
\hline \multicolumn{2}{|l|}{ Konten } \\
\hline $\begin{array}{ll}\text { a. Perubahan dan hubungan } \\
\text { (change and relationship) }\end{array}$ & 0 \\
\hline $\begin{array}{l}\text { b. Ruang dan bentuk (space and } \\
\text { shape) }\end{array}$ & 12,44 \\
\hline c. Kuantitas (quantity) & 67,16 \\
\hline $\begin{array}{llr}\text { d. } & \text { Ketidakpastian dan data } \\
\text { (uncertainty and data) } & \\
\end{array}$ & 20,4 \\
\hline \multicolumn{2}{|l|}{ Proses } \\
\hline $\begin{array}{ll}\text { a. } & \text { Menggunakan } \\
\text { matematika, fakta, prosedur, } \\
\text { dan penalaran }\end{array}$ & 66,17 \\
\hline $\begin{array}{l}\text { b. Merumuskan masalah secara } \\
\text { matematis }\end{array}$ & 21,39 \\
\hline $\begin{array}{l}\text { c. Menafsirkan, menerapkan, dan } \\
\text { mengevaluasi hasil matematika }\end{array}$ & 12,44 \\
\hline \multicolumn{2}{|l|}{ Konteks } \\
\hline a. Pribadi (personal) & 25,87 \\
\hline
\end{tabular}

\begin{tabular}{|clc|}
\hline b. & Pekerjaan (occupational) & 27,36 \\
\hline c. & Umum (societal) & 42,29 \\
\hline d. & Keilmuan (scientific) & 4,48 \\
\hline
\end{tabular}

Konteks umum (societal) menjadi konteks yang dominan dalam buku tersebut dengan persentase 42,29\%. Konteks umum berbicara tentang pada perspektif masyarakat dalam memandang hal-hal yang terjadi secara umum di masyarakat. Konteks umum yang banyak terdapat pada buku berkaitan dengan kegiatan yang terjadi di sekolah seperti minat peserta didik dalam pelajaran. Selanjutnya, konteks keilmuan menjadi konteks yang paling sedikit dijumpai dalam buku teks. Persentase konteks keilmuan hanya mencapai 4,48\%. Konteks keilmuan yang terdapat pada buku diantaranya membahas tentang kesehatan yang meliputi detak jantung, suhu tubuh dan nilai gizi dari suatu makanan.

Berdasarkan Tabel 3 terlihat bahwa aspek proses pada bagian menggunakan konsep matematika, fakta, prosedur, dan penalaran memiliki persentase jumlah soal daripada proses yang lain dengan persentase $66,17 \%$. Hal tersebut berarti bahwa lebih dari setengah soal pada buku teks yang serupa dengan PISA menerapkan aspek proses tersebut. Selanjutnya pada aspek proses pada komponen merumuskan masalah secara matematis dengan persentase 21,39\%. Dalam komponen perumusan masalah matematika, peserta didik perlu mengetahui pada bagian mana mereka dapat mengolah informasi 
matematis untuk memcahkan masalah yang disajikan. Pada komponen terakhir pada aspek proses adalah menafsirkan, menerapkan, dan mengevaluasi hasil matematika dengan persentase 12,44\%. Hasil tersebut menunjukkan bahwa komponen pada aspek proses pada buku teks masih belum merata.

Salah satu contoh soal dengan konteks keilmuan dapat dilihat pada Gambar 2

Sains. Jantung tikus berdetak 840 kali dalam 2 menit, jantung marmut berdetak 1.200 kali dalam 4 menit, dan jantung kelinci berdetak 1.025 kali dalam 5 menit. Hewan manakah yang berdetak lebih banyak dalam satu jam?

Gambar 2. Contoh Konteks Keilmuan

Soal pada Gambar 2 memiliki konteks kegiatan pengukuran detak jantung pada tikus dan marmut. Kegiatan tersebut dilakukan oleh seorang peneliti, dokter hewan atau seseorang yang memiliki ilmu untuk melakukan kegiatan tersebut. Konteks ilmiah seperti itu sangat jarang ditemui di buku teks. Buku teks hanya memiliki 9 soal yang memiliki konteks ilmiah dari total jumlah soal yang serupa dengan PISA. Berdasarkan hasil analisis pada aspek konteks dapat dikatakan bahwa aspek konteks pada buku masih belum merata.

Selain aspek konteks, analisis juga dilakukan berdasarkan aspek proses. Proses matematika dalam PISA merupakan tahapan-tahapan matematis dalam memecahkan masalah pada situasi atau konteks tertentu. Terdapat 3 aspek proses matematika yang terdapat pada PISA 2018

2. Seorang pengusaha mengeluarkan Rpl.000.000,00 untuk menjalankan usahanya. Jika pada hari itu dia menanggung kerugian sebesar Rp250.000,00, maka besarnya pendapatan yang didapatkan pada hari itu adalah ...

Gambar 3. Contoh Proses Employ

Selanjutnya adalah proses formulate, dalam proses ini, peserta didik mampu mengenali dan mengidentifikasi peluang untuk menggunakan matematika dan kemudian menyediakan struktur matematika untuk masalah yang disajikan dalam beberapa bentuk kontekstual

yang meliputi employ, formulate, dan interpret. menggunakan konsep matematika, fakta, prosedur, dan penalaran. Dalam proses ini peserta didik memiliki kemampuan untuk menerapkan konsep-konsep matematika, fakta, prosedur, dan penalaran seperti melakukan perhitungan aritmatika, kesimpulan logis dari asumsi matematika, melakukan manipulasi simbolik (OECD, 2019). Proses tersebut memiliki persentase yang paling dominan diantara proses yang lain dengan perserntase $66,17 \%$. Indikator dari soal-soal yang menerapkan proses prosedur, dan penalaran adalah soal memuat beberapa konsep matematika secara implisit, sehingga membutuhkan sedikit penalaran untuk dapat dinyatakan secara eksplisit. Selain itu, soal dapat diselesaikan hanya dengan perhitungan matematika atau rumus, contoh soalnya dapat dilihat pada gambar 3 . 
(OECD, 2019). Dalam proses merumuskan situasi matematis, peserta didik menentukan pada bagian mana pada soal yang dapat dimodelkan ke dalam bentuk matematika untuk dapat dianalisa agar mendapatkan penyelesaian. Pada buku teks, soal yang memuat proses ini hanya memiliki persentase 21,39\% dari jumlah soal yang serupa dengan PISA. Soal-soal yang memuat proses merumuskan masalah secara sistematis memiliki indikator yaitu soal memuat situasi yang memiliki informasi yang saling terkait dan memiliki peluang untuk direpresentasikan ke dalam model matematika. Informasi yang saling terkait pada soal dapat diinterpretasikan secara matematis menggunakan variabel yang tepat, simbol, diagram, dan model standar, contoh soalnya dapat dilihat pada gambar 4.

0. Sebuah mobil memerlukan satu liter bensin untuk menempuh jarak $12 \mathrm{~km}$. Hubungan antara banyak bensin yang dibutuhkan dengan jarak yang ditempuh digambarkan seperti pada grafik berikut.

Dengan menggunakan grafik berikut, dapatkah kalian menentukan persamaan yang terbentuk? Berapakah banyak liter bensin yang dibutuhkan mobil untuk menempuh jarak $72 \mathrm{~km}$ ? Berapakah jarak yang ditempuh mobil jika bensin yang dibutuhkan sebanyak 6,5 liter? (Anggaplah perjalanan yang ditempuh lancar, tanpa hambatan dan kemacetan)

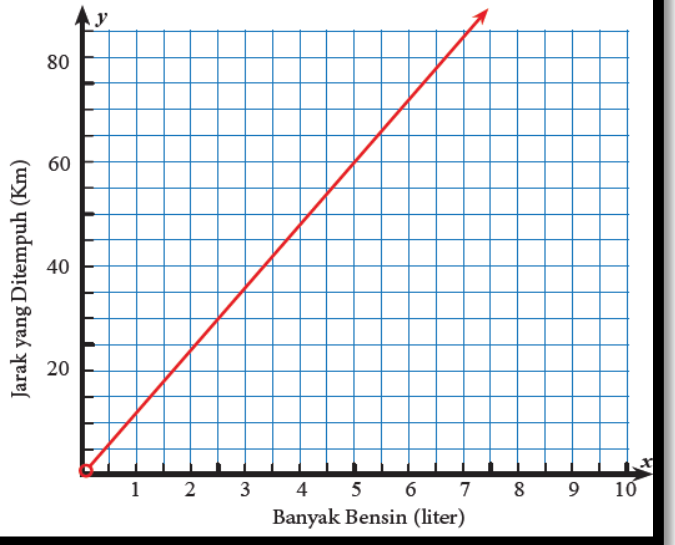

Gambar 4 Contoh Proses Formulate
Soal memuat grafik yang menyatakan hubungan antara banyak bensin (liter) dengan jarak yang ditempuh (Km). Selanjutnya peserta didik diminta untuk menentukan banyak bensin yang dibutuhkan mobil untuk menempuh jarak $72 \mathrm{~km}$. Selain itu peserta didik diminta untuk menentukan jarak yang ditempuh mobil jika bensin yang dibutuhkan adalah 6,5 liter. Soal tersebut tidak dapat diselesaikan hanya dengan melihat tabel karena informasi pada tabel terbatas. Soal tersebut dapat diselesaikan dengan membuat rumus untuk menghitung banyak bensin dan jarak berdasarkan informasi pada grafik. Pada grafik terdapat informasi bahwa dengan bensin 5 liter mobil dapat menempuh jarak $60 \mathrm{~km}$. Informasi tersebut dapat diinterpretasikan ke dalam bentuk matematika menjadi $\frac{\text { bensin }}{\text { jarak }}=\frac{5}{60}$ atau dapat disederhanakan menjadi $\frac{\text { bensin }}{\text { jarak }}=\frac{1}{12}$ . Selanjutnya bentuk itu dapat digunakan untuk menentukan banyaknya bensin maupun jarak yang ditempuh mobil.

Proses yang terakhir adalah interpret. Proses ini meliputi kegiatan menafsirkan, menerapkan, dan mengevaluasi hasil matematika. Fokus dari proses ini adalah kemampuan peserta didik untuk merenungkan solusi matematika, atau kesimpulan dan menafsirkan masalah dalam konteks kehidupan nyata (Afriansyah dan Dahlan, 2017; OECD, 2019). Peserta didik yang terlibat dalam proses ini dapat membangun dan mengkomunikasikan penjelasan dan 
argumen dalam konteks masalah, mencerminkan pada proses pemodelan dan hasilnya. Soal yang memuat proses ini hanya memiliki persentase $12,44 \%$ dari soal-soal yang serupa dengan PISA. Hasil tersebut menunjukkan bahwa masih sedikit soal pada buku teks yang memuat proses tersebut. Indikator soal yang memuat proses menafsirkan, menerapkan, dan mengevaluasi hasil matematika adalah soal yang memuat informasi / pertanyaan yang memunculkan asumsi atau memuat berbagai data sebagai pembanding atau menerapkan suatu algoritma matematika yang dapat diproses untuk menghasilkan kesimpulan dan kemudian dapat dievaluasi. Contoh soal pada buku teks yang memuat proses ini dapat dilihat pada Gambar 5.

Populasi. Berikut data jumlah penduduk dan luas wilayah empat kabupaten "Tapal Kuda” Jawa Timur tahun 2006.

Populasi jumlah penduduk empat kabupaten di Jawa Timur tahun 2006

\begin{tabular}{|l|c|c|}
\hline \multicolumn{1}{|c|}{ Kabupaten } & Jumlah Penduduk & Luas Wilayah (km²) \\
\hline Banyuwangi & 1.575 .086 & 5.783 \\
\hline Bondowoso & 708.683 & 1.560 \\
\hline Jember & 2.298 .189 & 2.478 \\
\hline Situbondo & 641.692 & 1.639 \\
\hline
\end{tabular}

Sumber: Data Proyeksi BPS Tahun 2006 (www.dinkesjatim.go.id)

Rima mengatakan bahwa kabupaten yang memiliki kepadatan penduduk per $\mathrm{km}^{2}$ yang rendah adalah Kabupaten Situbondo, karena memiliki jumlah penduduk yang paling sedikit.

Apakah pernyataan yang disampaikan Rima benar? Jelaskan.

Gambar 5. Contoh Proses Interpret

Soal tersebut dapat memunculkan asumsi peserta didik bahwa semakin sedikit jumlah penduduk maka kepadatannya juga semakin kecil. Selanjutnya soal memuat 4 informasi pembanding yang perlu dicari dahulu kepadatan penduduk dari tiap daerah. Informasi tersebut dapat diperoleh dengan menerapkan konsep perbandingan yang telah dipelajari yaitu dengan menentukan jumlah penduduk untuk $1 \mathrm{~km}^{2}$ Setelah diperoleh informasi mengenai kepadatan penduduk dari masing-masing daerah maka dapat disimpulkan daerah mana yang memiliki kepadatan penduduk terendah. Kesimpulan tersebut dapat digunakan untuk menentukan kebenaran dari pendapat Rina. Berdasarkan hasil analisis pada aspek proses dapat dikatakan bahwa aspek proses pada buku masih belum merata.

Analsis yang dilakukan pada buku teks juga memiliki tujuan untuk mengetahui sampai dimana buku tersebut dapat melatih kompetensi matematika peserta didik berdasarkan level kompetensi matematika PISA. Level kompetensi matematika pada PISA terbagi menjadi 6 level yang mana setiap levelnya memiliki kompetensi matematika tertentu.

Dengan level tersebut dapat mengidentifikasi seberapa jauh kemampuan literasi dari seorang peserta didik. Hasil analisis dapat dilihat pada Tabel 4 yang memuat klasifikasi soal berdasarkan level kompetensi matematika PISA.

Tabel 4.

Klasifikasi Soal Berdasarkan Level Kompetensi

\begin{tabular}{|c|c|c|}
\hline \multicolumn{3}{|c|}{ Matematika PISA } \\
\hline $\begin{array}{l}\text { Level } \\
\text { Kompetensi } \\
\text { Matematika } \\
\text { PISA }\end{array}$ & Jumlah & Persentase \\
\hline Level 1 & 80 & $39,80 \%$ \\
\hline Level 2 & 106 & $52,74 \%$ \\
\hline
\end{tabular}




\begin{tabular}{|ccc|}
\hline Level 3 & 3 & $1,49 \%$ \\
\hline Level 4 & 11 & $5,47 \%$ \\
\hline Level 5 & 1 & $0,50 \%$ \\
\hline Level 6 & 0 & $0 \%$ \\
\hline
\end{tabular}

Pada Level 1 kompetensi matematika PISA, peserta didik dapat menjawab pertanyaan yang melibatkan konteks yang sudah dikenal di mana semua informasi yang relevan ada dan pertanyaanpertanyaannya didefinisikan dengan jelas. Indikator soal yang dapat melatih kompetensi pada level 1 diantaranya adalah harus memuat konteks kegiatan sehari-hari dan setiap informasi yang diperlukan untuk menyelesaikan soal disajikan dengan jelas. Sebagai contohnya adalah soal yang dapat dilihat pada Gambar 6.

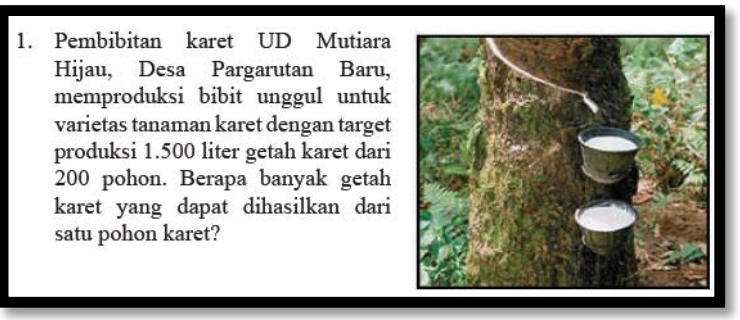

Gambar 6. Contoh Soal pada Level 1

Soal tersebut memuat kegiatan pembibitan pohon karet untuk memproduksi getah karet dari pohon karet. Kegiatan tersebut termasuk ke dalam konteks umum karena kegiatan tersebut dilakukan oleh suatu komunitas atau masyarakat. Jika dilihat dari aspek konten, soal tersebut memuat materi perbandingan sehingga termasuk ke dalam konten bilangan. Dalam soal tersebut, peserta didik diminta untuk menentukan banyak getah karet yang dapat dihasilkan dari satu pohon karet. Informasi yang dibutuhkan untuk menyelesaikan soal tersebut telah disajikan dengan jelas dengan diketahui bahwa untuk memproduksi 1.500 liter getah karet diperlukan 200 pohon karet. Informasi tersebut sudah cukup untuk menyesaikan soal tersebut. Proses yang digunakan dalam penyelesaian adalah dengan menggunakan konsep matematika yang terdapat pada soal secara implisit yaitu perbandingan. Dengan menggunakan penalaran yang baik, peserta didik akan dapat menyelesaikannya.

Berdasarkan hasil analisis, soal-soal pada buku teks yang mencapai level 2 memiliki persentase $52,74 \%$. Pada level ini peserta didik dapat menafsirkan dan mengetahui situasi dalam konteks yang membutuhkan penarikan kesimpulan secara langsung. Mereka dapat mengekstraksi informasi yang relevan dari satu sumber agar dapat digunakan untuk mempresentasikannya. Peserta didik di tingkat ini dapat menggunakan algoritma, rumus, prosedur, atau konvensi dasar untuk memecahkan masalah yang melibatkan bilangan bulat. Ciri-ciri soal yang dapat melatih kemampuan pada level 2 adalah soal memuat berbagai macam informasi baik yang relevan atau tidak sehingga setiap informasi perlu disimpulkan terlebih dahulu apakah informasi tersebut berguna atau dapat diolah lebih lanjut untuk menyelesaikan permasalahan. Selain itu, soal tersebut dapat diselesaikan hanya menggunakan 
algoritma, rumus, prosedur, atau konvensi dasar. Sebagai contohnya adalah soal yang dapat dilihat pada Gambar 7.

Suatu ketika Pak Hadi memberi dua karung beras dengan jenis yang berbeda. Karung pertama tertulis neto $25 \mathrm{~kg}$ dibeli dengan harga Rp260.000,00. Karung kedua tertuliskan neto 25 dibeli dengan harga Rp280.000,00. Pak Hadi mencampur kedua jenis beras tersebut, kemudian mengemasinya dalam ukuran neto $5 \mathrm{~kg}$. Tentukan harga jual beras tersebut agar Pak Hadi untung 20\%.

Gambar 7. Contoh Soal pada Level 2

Jumlah soal yang mencapai level 2 kompetensi matematika PISA berbanding terbalik dengan jumlah soal pada level 3. Persentase jumlah soal pada level 3 hanya mencapai 1,49\% atau hanya terdapat 3 soal pada buku teks tersebut yang memiliki level 3 kompetensi matematika PISA. Pada level 3, peserta didik dapat menjalankan prosedur yang dijelaskan dengan jelas, termasuk yang membutuhkan urutan keputusan dan strategi pemecahan masalah. Jenis soal yang dapat melatih kompetensi pada level 3 adalah soal yang memuat suatu prosedur di dalamnya. Salah satu contoh prosedur yang dimaksud adalah berupa rumus yang dikhususkan untuk menyelesaikan soal tersebut.

Selanjutnya adalah level 4 kompetensi matematika PISA. Level 4 memiliki jumlah soal lebih banyak daripada level 3 dengan persentase $5,47 \%$ dari total soal yang serupa dengan PISA. Pada level ini, peserta didik dapat bekerja secara efektif dengan model eksplisit untuk situasi konkret kompleks yang mungkin melibatkan kendala atau panggilan untuk membuat asumsi. Mereka dapat membangun dan mengkomunikasikan penjelasan dan argumen berdasarkan interpretasi, argumen dan tindakan mereka. Jenis soal yang memuat kompetensi level 4 ini memiliki beberapa indikator. Pertama adalah soal memuat situasi yang kongkret dan kompleks. Kedua, soal memuat informasi yang menimbulkan asumsi peserta didik. Selanjutnya, Penyelesaian soal memerlukan transformasi masalah ke model matematika.

Pada level 5 hanya terdapat 1 soal yang ditemukan dalam buku. Terdapat hal yang menarik dari soal tersebut karena soal tersebut merupakan soal dari PISA. Pada level ini, peserta didik dapat memilih, membandingkan, dan mengevaluasi strategi penyelesaian masalah yang tepat untuk menangani masalah rumit yang terkait dengan model ini.

Kompetensi pada level 6 ini adalah peserta didik dapat membuat konsep, menggeneralisasi dan memanfaatkan informasi berdasarkan investigasi dan pemodelan situasi masalah yang kompleks, dan dapat menggunakan pengetahuan mereka dalam konteks yang relatif tidak standar. Soal-soal dengan level ini memerlukan kemampuan generalisasi dan penalaran tingkat tinggi. Berdasarkan hasil analisis, buku teks belum memuat soal yang sesuai dengan level 6 kompetensi matematika PISA. Dalam pembelajaran matematika tentunya perlu diperkenalkan kompetensi pada level 6, walaupun umumnya tidak termuat dalam buku teks, pengenalan dapat dilakukan melalui model pembelajaran berbasis proyek yang 
dimodifikasi yang telah teruji dapat

meningkatkan kemampuan literasi matematika siswa (Priyambodo \& Maryati, 2019).

\section{Penutup}

Berdasarkan hasil analisis buku teks yang ditinjau dari kemampuan literasi matematika, banyaknya soal-soal yang tidak sesuai dengan aspek penilaian PISA lebih banyak daripada soal yang sesuai dengan aspek penilaian PISA. Soal-soal yang disajikan kebanyakan tanpa adanya konteks. Akibatnya, peserta didik tidak terbiasa mengerjakan soal dengan konteks yang melibatkan kegiatan dunia nyata. Peserta didik hanya akan terpaku pada rumus yang telah mereka hafalkan tanpa memahami konteks yang telah disajikan. Oleh karena itu, soal-soal tersebut perlu diperbaiki dengan menambah konteks pada setiap soalnya. Diperlukan sumber belajar lainnya yang dapat melengkapi kekurangan dari buku teks dalam upaya meningkatkan kemampuan literasi matematis siswa.

\section{Daftar Pustaka}

Afriansyah, E. A., \& Dahlan, J. A. (2017). Design Research in Fraction for Prospective Teachers. The 5th SEA-DR (South East Asia Development Research) International Conference 2017 (SEADRIC 2017). Advances in Social Science, Education, 100. 91-97. Čeretková, S., Šedivý, O., Molnár, J., \& Petr, D. (2008). The role and assessment of textbooks in mathematics education.
Paper presented at the Problems of Education in 21st Century

Depdiknas. (2006). Peraturan Menteri Pendidikan Nasional 22 Tahun 2006.

De Porter, B. \& Hernacki, M. (1992). Quantum Learning. Membiasakan Belajar Nyaman dan Menyenangkan. Terjemahan oleh Alwiyah Abdurrahman. Bandung: Penerbit Kaifa.

Fatwa, V. C., Septian, A., \& Inayah, S. (2019). Kemampuan Literasi Matematis Siswa melalui Model Pembelajaran Problem Based Instruction. Mosharafa: Jurnal Pendidikan Matematika, 8(3). 389-398

IEA. (2012). TIMSS 2011 encyclopedia: Education policy and curriculum in mathematics and science. Chestnut Hill, MA: TIMSS \& PIRLS International Study Center, Boston College

Kajander, A., \& Lovric, M. (2009). Mathematics textbooks and their potential role in supporting misconceptions. International Journal of Mathematical Education in Science and Technology, 40(2), 173-181

Krippendorf, K. (2013). Content analysis: An introduction to its methodology (Second ed.) Thousand Oaks, CA: Sage Peblications, Inc.

Li, Y., Zhang, J., \& Ma, T. (2009). Approaches and practices in developing school mathematics texbooks in China. ZDM - The International Journal on Mathematics Education, 41. 733-748.

Lyche, T., \& Morken, K.. (2004). Spline Methods, Draft, Retrieved from http://www.ub.uio.n./umn/english/in dex.html, on 23th Feb 2005. 
Masduki, Subandriah, M. R., Irawan, D. Y., Prihantoro, A. (2013). Level Kognitif soal-soal Pada Buku Teks Matematika SMP Kelas VII. Prosiding Seminar Nasional Matematika dan Pendidikan Matematika FMIPA UNY.

Matic, L. J., \& Gracin, D., G. (2016). The use of the textbook as an artefact in the classroom A case study in the light of a socio-didactical tetrahedron. J Math Didakt, 37. 349-374.

Muslich, M. (2010). Textbook Writing, Dasar-dasar Pemahaman, Penulisan, dan Pemakaian Buku Teks. Yogyakarta: Ar-Ruzz Media

Muzaki, A., \& Masjudi. (2019). Analisis Kemampuan Literasi Matematis Siswa. Mosharafa: Jurnal Pendidikan Matematika, 8(3). 493-502.

OECD. (2019). PISA 2018 Assessment and Analytical Framework.

Ojose, B. (2011). Mathematics Literacy: are we able to put the mathematics we learm into everyday use. Journal of Mathematics Education, 4(1). 89-100.

Priyambodo, S., \& Maryati, I. (2019). Peningkatan Kemampuan Literasi Statistis melalui Model Pembelajaran Berbasis Proyek yang Dimodifikasi. Mosharafa: Jurnal Pendidikan Matematika, 8(2). 273-284.

Smith, P. L., \& Ragan, T. J. (2005). Instructional design (Third ed.) Huboken, NJ: John Wiley \& Sons, Inc.

TIMSS \& PIRLS International Study Center, Boston College.

Wijaya, A. (2013). Pentingnya analisis buku peserta didik dalam implementasi kurikulum 2013. PPPPTK Matematika. 1-4.

Wijaya, A., Van den Heuvel-Panhuizen, M., \& Doorman, M. (2015). Opportunity-
to-Learn context-based tasks provided by mathematics textbooks. Educational Studies in Mathematics, 89(1). 41-65.

World Bank. (2010). Inside Indonesia's mathematics classrooms: A TIMSS video study of teaching practices and student achievment. Jakarta: The World Bank Office.

\section{Riwayat Hidup PenUlis}

Erik Suharyono, S.Pd

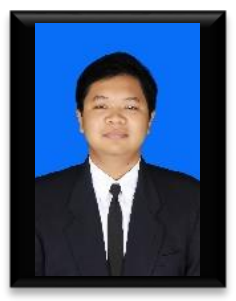

Lahir di Gunungkidul, 8 Juli 1997. Studi S1 Pendidikan Matematika Universitas Negeri Yogyakarta, Yogyakarta, lulus tahun 2020

\section{Dr. R. Rosnawati, M.Si.}

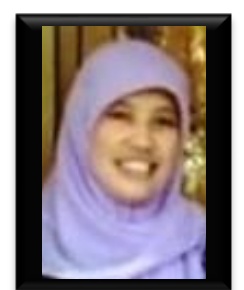

R. Rosnawati, Lecturer in the Mathematics Education, FMIPA, Yogyakarta State University of Indonesia. Doctorates in educational research and evaluation, study programs with researches that have been conducted include mathemactical reasoning in junior high school, developing critical thinking skills instrument, high order thingking skills in mathematic education, as well as several other studies. 